\title{
MERTK wt Allele
}

National Cancer Institute

\section{Source}

National Cancer Institute. MERTK wt Allele. NCI Thesaurus. Code C52175.

Human MERT K wild-type allele is located in the vicinity of 2 q14.1 and is approximately $131 \mathrm{~kb}$ in length. This allele, which encodes proto-oncogene tyrosine-protein kinase MER protein, plays a role in tissue homeostasis and receptor signaling. Mutations in the gene have been associated with disruption of the retinal pigment epithelium phagocytosis pathway and onset of autosomal recessive retinitis pigmentosa. 